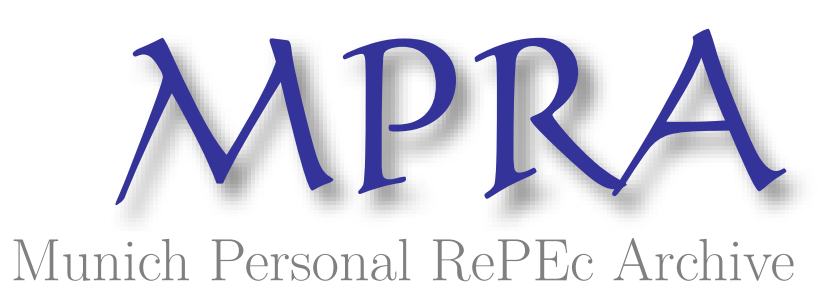

\title{
Viewing tax policy through party-colored glasses: What German politicians believe
}

Janeba, Eckhard and Heinemann, Friedrich

University of Mannheim

August 2011

Online at https://mpra.ub.uni-muenchen.de/33096/

MPRA Paper No. 33096, posted 01 Sep 2011 12:32 UTC 


\title{
Viewing tax policy through party-colored glasses: What German politicians believe
}

\author{
Friedrich Heinemann (ZEW Mannheim) \\ Eckhard Janeba (University of Mannheim, CESifo and ZEW)
}

Revised version, May 2010

\begin{abstract}
The process of globalization has an important impact on national tax policies. Most of the literature does not focus directly on the political decision making process and assumes that the desired tax policy is responding to objective underlying tradeoffs. Based on an original survey of members of German national parliament (Bundestag) in 2006/7 we document a strong ideological bias among policy makers with respect to the perceived mobility of international tax bases (real capital and paper profits). Ideology influences also directly and indirectly the perceived national autonomy in tax setting and preferences for a EU minimum tax for companies. There seems little consensus as to what the efficiency costs of capital taxation in open economies are, even though our survey falls in a period of extensive debate about and actual adoption of a company tax reform bill in Germany.
\end{abstract}

JEL Classification Code: D78, D83, H25

Keywords: Globalization, business taxation, beliefs, member of parliament, profit shifting, party discipline, yardstick competition

Friedrich Heinemann

Centre for European Economic Research

(ZEW)

L7, 1

68161 Mannheim

Germany

++49-621-1235149

Heinemann@zew.de

* Corresponding author
Eckhard Janeba*

Department of Economics

University of Mannheim

L7, 3-5

68131 Mannheim

Germany

++49-621-181 1795

janeba@uni-mannheim.de. 


\section{Introduction}

A common characteristic of the literature on tax policy in open economies and the tax competition in particular is that a country's tax policy is modelled to be constrained by neighbouring countries' fiscal policy (see Wilson, 1999, for a survey). The mechanisms of competition which potentially constrain national tax policy are diverse. They range from the mobility of capital and firms (Zodrow and Mieszkowski, 1986, and Wilson, 1986) over the mobility of paper profits within multinational corporations (Mintz and Smart, 2004) up to yardstick competition phenomena where voters base their voting decision on the comparison between the domestic and foreign fiscal policies (Besley and Case, 1995).

While both the theoretical and empirical literature on tax competition has reached an advanced stage, one assumption is rarely questioned: political decision makers are assumed to have an unbiased perception of tax policy constraints. Tax setting jurisdictions are regularly modelled as agents who - based on full and undistorted information with respect to the tax elasticity of tax bases - maximize their utility by choosing the level of taxation or the definition of the tax base. As a result, for a given environment tax policies of jurisdictions may differ as a consequence of differences in the preferences over an equity-efficiency trade off. Yet, the efficiency costs of levying taxes on mobile factors are assumed to be objective or at least to be perceived the same across decision makers (if distorted).

We question this assumption and put it to an empirical test. We document a strong ideological bias among policy makers with respect to the perceived mobility of international tax bases. In contrast to the implicit assumption in the literature cited above there seems to be little consensus among policy makers as to how mobile firms and paper profits in an open economy are and hence what the efficiency cost of capital taxation are. Our findings are based on an original survey of members of the German national parliament (Bundestag) relating to their views on business tax policy. We do not only find an ideological bias in the perception of international mobility of tax bases, but we more generally detect the factors that influence the views of policy makers. Our survey identifies the members of parliament (MP) by name and hence we are in a position to condition the results on various control variables such as education of and information available to policy makers.

The survey was conducted in late 2006 and early 2007. While not all members of parliament can be expected to be experts on tax policy, reform of company taxation was put high on the agenda by the coalition of Christian and Social Democrats governing Germany since late 2005. For this reason various tax reform proposals were discussed in the public during 2005-7 and a specific business tax reform bill was passed by the German Bundestag a few 
months after our survey in May 2007. The timing of our questionnaire thus falls in a period of general awareness about the international dimension of tax policy. The reason for the government's priority of reforming company taxation at that time was the high level of taxation in Germany, despite an earlier reform under the previous government that already lowered the tax burden for corporations and non-corporations. Both in terms of statutory and effective marginal corporate tax rates Germany ranked highest among EU countries, and after the Eastern enlargement of the EU, Germany borders or is close to countries with much lower tax rates (see for example Devereux et al., 2002, and for more recent data Haufler, 2006).

Our main findings are as follows: First, ideological bias matters in explaining the politicians' views on the three globalization and tax policy channels, and the bias matters quantitatively more than most other control variables such as the politician's profession, membership in economics related parliament committees, years in parliament, and educational degree. In particular, there is a clear left-right bias in perception of real corporate mobility in response to taxation. More left-wing politicians regard taxation as less important in company location decisions than right-wing politicians. However, the ideological bias is not always monotonic. Members of the center-left Social Democrats (SPD) believe that international profit shifting is much more prevalent than more right wing or liberal parties such as the center-right Christian Democrats (CDU/CSU) and market-oriented Free Democrats (FDP), as well as the far Left party.

Second, we obtain interesting insights with respect to the impact of the election mode by exploiting a particular feature of the German electoral system: About fifty percent of legislators in the German parliament are elected directly in districts, while the other half is elected via a state party list, where seats are allocated to parties based on vote shares. Interestingly, party list MPs with arguably less direct contacts to regional constituencies perceive a lower real tax elasticity of companies compared to directly elected politicians. This result is in spirit of Stratmann and Baur (2002) who also exploit the differential election channel of German members of parliament. They find that directly elected politicians serve on committees that allow them to provide benefits to their district constituencies, while party list candidates serve on committees that provide benefits to the general party constituency (not geographically concentrated).

Third, the yardstick competition hypothesis finds relatively little support in the German Bundestag. In general, German politicians don't believe that voters care much about other countries' tax policies. Controlling again for the politician's mode of election, however, 
we find that directly elected politicians believe more strongly in the role of voters' perception of other countries' tax policies.

We get our fourth finding when we proceed to explain the perceived degree of national autonomy in tax setting and use the answers to the three previous questions (the channels of globalization and tax policy) as explanatory variables. In addition, we also allow party membership to directly explain the responses by legislators. Political economy considerations suggest that through the personal interest of a politician (e.g., high own capital income) party affiliation could matter if party membership were highly correlated with capital income. We find again a strong direct ideological bias. Ideology matters also indirectly, in particular via its impact on the perception of the profit shifting channel. Hence, party membership matters both directly and indirectly.

Finally and fifth, we use the same approach to explain preferences for EU tax harmonization and find that minimum tax rates for companies are more strongly favoured by left wing parties, even after controlling for the three globalization and tax policy channels. The direct ideology effect is quantitatively more important than the three channels of globalization. Perhaps surprisingly, directly elected politicians tend to be more in favour of minimum tax rates.

Robustness checks indicate that our key results are not distorted by a possible selection bias in the survey, which we accomplish by making use of a student control group. We also seek alternative confirmation that party membership in the Bundestag has indeed information content with respect to the MP's tax ideology. To this end we employ an indicator on party ideology from Benoit and Laver (2006) as an alternative to party dummies. The robustness checks broadly confirm our general findings.

To the best of our knowledge there exists hardly any survey based analyses of tax policy decision makers with the exception of contributions on politicians from Flemish municipalities (Ashworth and Heyndels, 1997, 2000). These authors survey local spokesmen of different parties in all Flemish municipalities with respect to their views on tax policy. Ashworth and Heyndels (1997) investigate the politicians' opinion whether they regard their municipality's level of taxes as "low" or "high". Their results indicate that factors like the ideological position or tax levels in neighbouring jurisdiction influence this subjective assessment. Ashworth and Heyndels (2000) scrutinize how politicians prefer to change different types of taxes if tax revenues need to be raised or cut. They diagnose an asymmetry according to which tax cuts are concentrated upon one tax instrument (income tax) whereas tax increases tend to be diversified between different taxes. While the conceptual distinction between be- 
liefs on tax policy constraints and ideological attitudes towards taxation plays a role in these contributions, the analyses do neither focus on restrictions from real investment or paper profit mobility nor do they include respective questions.

Our paper is structured as follows. In the next section we summarize what the tax competition literature assumes about political perceptions on constraints and contrast this with recent insights on the role of ideology and biases in the economic literature. In section 3, we provide relevant information relating to the German electoral and political system and the debate about company tax reform. We describe the survey and provide a summary of the data in section 4. In section 5 we present the structure of a simple two step approach in the formation of tax policy opinion and the estimation methodology. Subsequently, we turn in section 6 to our key findings. Various robustness checks are analyzed in section 7 before we conclude with a hint to possible mechanisms of belief formation that could explain our finding and ideas for future work.

\section{Biased perceptions}

Theoretical tax competition models are rooted in the tradition of optimum taxation and built on the ingredients of rational expectations and full information on the side of tax policy makers and other economic agents. The full information assumption regularly holds also with respect to the costs of taxation including, e.g., losses of tax base through mobility. This is the case in the seminal paper on real capital mobility, Zodrow and Mieszkowski (1986), who assume that identical jurisdictions compete for a fixed stock of capital. Subsequent modelling has widened the perspective by including further mobility phenomena. For example, Haufler and Schjelderup (2000) analyse the interactions of two countries allowing for the existence of foreign direct investment and profit shifting through manipulated transfer pricing. In this setting, the taxing country faces additional tax base losses due to paper profit mobility. What is essential in our context is that, again, jurisdictions' policy makers are modelled to have undistorted information on the elasticity of capital and profits.

A further extension represents the models of yardstick competition. In the Besley and Case (1995) model voters cannot observe directly the cost of providing public goods and whether politicians are "good" or "bad". By contrast, politicians are modelled to have full information. In particular, they know precisely how voters behave at the ballot box given their tax policy decision. The resulting strategic equilibrium is one of rational expectations both on the side of voters and incumbent politicians. 
This short overview on the distinct basic tax competition models illustrates that full information and an undistorted perception of both economic and political restrictions are an overriding characteristic of the literature. Jurisdictions may differ with respect to their preferences but they all have the same (perceived) level of information on the phenomena which enter their optimization problem. Even in the models where information is assumed to be asymmetric (as it is the case for voters and politicians in the yardstick competition model) these asymmetries are not related to ideology. The less informed players are modeled to have a larger uncertainty on the true state but are nevertheless assumed to be unbiased.

A testing strategy to substantiate this common approach of the literature, therefore, has to make a clear distinction between the perceptions of restrictions on the one hand and overall tax policy preferences on the other hand.

Different justifications exist to put the key assumption of undistorted perceptions of tax policy restrictions to a test. Increasingly, the economic literature acknowledges the role of ideology, cognitive biases and limited information to effectively influence policy outcomes. On the empirical level, a number of contributions have shown that laypeople have significantly different perceptions of economic phenomena compared to trained economists and that these differences point to biases in the general public's perception of economic phenomena (Caplan, 2002, Blinder and Krueger, 2004). The role of misconceptions and voter ignorance is explored in explaining views on domestic tax policy in the U.S., such as Krupnikov et al. (2006) and Birney et al. (2006) on the repeal of the estate tax, and Slemrod (2003) on the replacement of the income tax by a flat or retail sales tax. It is hard to argue that these biases substantiated for voters should necessarily be absent for political decision makers. On the theoretical level, there is an increasing literature on the role of ideological misperceptions and their possible strategic stability of ideological views: Caplan (2007) argues that systematic belief errors are individually rational if the belief itself has consumption value. In principle, individuals could update their belief in view of contrary evidence. Yet the incentive to do so is too small because in large societies any single person has basically zero chance of being pivotal in an election. Bénabou (2008) presents a model of collectively sustained misperceptions for the efficiency of market versus government provision of goods such as education, health insurance or pensions. In contrast to Caplan he does not take a particular stance as to whether the state or government better solves allocation problems. Rather he lets agents choose whether to process or ignore contrary evidence and the incentives to do so depend on the voting and private decisions of other agents in the economy. Thus social cognitions are endogenously derived and multiple equilibria are feasible, which makes public opinion path depend- 
ent. Alesina and Angeletos (2005) or Bénabou and Tirole (2006) propose the strategic stability of opposing view on the relative role of effort or luck for individual economic success. Contrasting outcomes with a small welfare state and the belief in self-responsibility ("American equilibrium") or a large welfare state and the belief that luck is crucial ("European equilibrium") are possible.

A common thread of all these contributions is that subjects may act individually rational if they do stick to biased perceptions and ignore signals that their beliefs on economic mechanisms are erroneous. Although these theories largely aim at explaining attitudes and decisions regarding the effectiveness of markets and governments, it is not hard to imagine that this type of logic can be applied in the context of taxation and the constraints associated with open markets. Our findings are consistent with the above explanations.

\section{Institutional background}

In this section we provide information on two items relating to our survey: first the German electoral and political system, and second company tax reform under way in Germany while the survey was conducted. A careful description and analysis of the German party and electoral system can be found in Roberts (1988) and Poguntke (1994).

\section{Germany's electoral and political system}

Germany is a parliamentary democracy with two chambers, the lower house (Bundestag) and the upper house (Bundesrat), the latter representing the 16 states of Germany. The Bundestag elects the chancellor and thus controls the executive. Our survey is based on members of the Bundestag (or "parliament" henceforth). The Bundestag consists of (at least) 598 members, who are elected every four years. There are 299 districts, and each district is represented by one person who is elected by plurality rule. The other half of the parliament is elected based on vote shares for state party lists. We exploit this unique aspect in our empirical analysis below. The overall seat allocation in parliament is based on national vote shares of the second vote (e.g., proportional representation) subject to the requirement that a party needs to catch at least $5 \%$ of the national vote or win three districts. ${ }^{1}$

\footnotetext{
${ }^{1}$ A peculiarity of the German electoral system is that the share of the second vote determines the share of total seats in parliament, even if a party has won more districts (based on the first vote) than it should obtain based on the second vote. For this reason excess seats (Überhangmandate) are granted to a party that has won more districts (from the first vote) than its proportional vote share would suggest. This explains why in the electoral period 2005-9 the Bundestag had $614(=598+16)$ members.
} 
Broadly speaking parties can be characterized as follows: The Christian Democrats (CDU/CSU) are a centre-right party, while the Social Democrats (SPD) represent the centreleft. The Free Democrats (FDP) are liberals in the sense of favoring a small government and low taxes, which makes them more market friendly than the Christian Democrats, who in turn are more market-oriented than the Social Democrats. The Left Party is drawing heavily on former communists in East Germany and disappointed Social Democrats from the left wing in West Germany. On economic policies the Left Party is to the left of the SPD. The Greens heavily focus on environmental and social policies with diverse views on economic issues, and are popular with relatively young, well educated people from the middle class.

\section{Company tax reform in Germany}

Prior to the 2008 corporate tax reform, tax rates in Germany on capital income, in particular corporate income, were high by international standards. For example, the nominal tax burden on retained profits in 2006 was about $37 \%$, consisting of a $25 \%$ corporate tax rate plus local tax and the so-called solidarity charge. This made Germany a high tax country among OECD and EU countries. A similar picture arose with respect to effective marginal tax rates (see Haufler, 2006, for recent data). For this reason the government made up by Social Democrats and Christian Democrats agreed to reform company taxation after establishing their coalition in November 2005. The major objective of the government was to make Germany's tax system more competitive internationally, in particular for domestic and foreign investors in real capital. At the same time, there was fear about the shifting of paper profits out of Germany by multinational firms through means of transfer pricing and thin capitalization, and thus rules for securing tax revenues in Germany are aimed at.

Shortly after our survey the coalition government of Christian and Social democrats presented a complex company tax and capital income tax reform bill (Deutscher Bundestag, 2007a). The main items of the bill, as relevant for the context of our survey, are the following:

- Reduction of nominal tax burden for retained profits by corporations from almost $39 \%$ to $29,83 \%$, mostly by a reduction of the corporate tax rate from 25 to $15 \%$.

- Provisions restricting the interest deductibility of loans for multinational firms.

- Some changes to the definition of the corporate tax and local tax (Gewerbesteuer), which on balance reduced the marginal effective tax rates. 
- The overall fiscal revenue loss is estimated to be 5 billion Euro annually in the long run (static effects, no behavioural adjustment assumed).

The bill was passed with minor modifications by the Bundestag and the upper house (Bundesrat) in May and July of 2007, respectively, and became effective on January 1, 2008. Of the majority coalition parties, two members of the Christian democrats abstained, while all others voted in support. For the Social Democrats two opposed the bill and 15 abstained. The three smaller parties all voted against the bill, albeit for very different reasons. ${ }^{2}$

\section{Survey and Data}

The survey among the members of the German Parliament (Bundestag) started in November 2006 and the last responses were recorded in February 2007. The legislators were contacted by written letters and subsequently by phone calls (when no initial response occurred). 157 members of the German Bundestag participated by returning filled questionnaires resulting in a response rate of 25.6 percent with substantial differences across parties (see Table 1). Possible concerns about the differential response rates are addressed in our estimation approach and in subsequent robustness checks.

The questionnaire included the following questions (original questions in German are available upon request) addressing perceptions of the three main channels of tax competition as discussed in the tax competition literature and some specific tax policy preferences:

The Globalization and Tax Policy Channels:

- Question 1 (Q1) on real corporate mobility: "The level of company taxation is mentioned as one factor for the location decision of companies. How important do you believe is the level of company taxation in this context?"

- Question 2 (Q2) on profit shifting: "Reports suggest that companies use tax planning strategies to shift paper profits from high-tax to low-tax jurisdictions. How widespread do you think is this phenomenon?"

\footnotetext{
${ }^{2}$ The FDP thought that the tax rate cuts were too small, while the Left Party felt they were too large. The Green Party feared that the revenue impact was entirely unclear, non-corporations did not benefit enough, and various provisions would reduce rather than stimulate investment.
} 
- Question $3(\mathbf{Q 3 )}$ on voter awareness: "Do you believe that voters consider tax rates in neighboring countries when forming an opinion on the appropriate level of company taxation in Germany?"

\section{$\underline{\text { Policy Questions: }}$}

- Question 4 (Q4) on national autonomy: "Some people feel that globalization leads to a loss in national autonomy. Do you think that Germany still has any autonomy in the area of company taxation?"

- Question 5 (Q5) on EU minimum tax: "In the current debate some have suggested that the EU should introduce a minimum tax for companies. Are you in favour of this proposal?"

Answers could be given on a discrete scale from 1 ("not at all") to 9 ("very much").

The survey was conducted non-anonymously. However, confidentiality of individual responses was guaranteed. Hence, participating MPs had not to expect that either their party colleagues or voters would learn about their individual answers. In this respect, a confidential study like ours is superior to the analysis of recorded votes. Recorded votes, by definition, are public with the consequence that divergence from the party line or from voter preferences is threatened by sanctions. A fully anonymous survey which might reduce incentives to disguise a MP's true beliefs even further is not an alternative. Full anonymity would preclude the identification of MPs individual characteristics which are indispensible for a meaningful analysis.

Apart from party membership as the key variable for a MP's ideological position we took account of variables related to a member's education (tertiary degree), level of specialized information (proxied e.g. by membership in financial committee) and a group of further variables as summarized in Table 2 (for descriptive statistics see Table 3). This information was compiled from the Bundestag website ${ }^{3}$. While the precise classification of variables is debatable, in particular the distinction between education and information variables, the classification is helpful in our view. Education should be relevant for the ability to process information, and the educational specialization (e.g., on economics or business) should hint towards the degree of information about globalization restrictions. Similarly we would expect that certain professional experience (e.g. as a self-employed), the length of Bundestag membership, and the membership in specialized Bundestag committees serve as useful proxies for

\footnotetext{
${ }^{3}$ www.bundestag.de which also presents the MP's CVs.
} 
the degree of information on the tax policy environment. The inclusion of economic education and specialized committee membership in the subsequent testing also alleviates a subtle problem in the answer patterns: ${ }^{4}$ It may simply be the case that individuals who do not care about location decision of firms will answer that the tax elasticity is low. Since economic knowledge and expertise serve as a natural proxy for the importance assigned to the issue of firm mobility we thus limit the risk that ideological heterogeneity of perceptions simply mirrors the variance in importance assigned to the topic in general.

Among other variables we include dummies to differentiate between Eastern and Western German, male and female, direct and party list MPs. We also account for age. The heterogeneity of the economic and political environment in Eastern and Western Germany may impact results also because Eastern Germans have a different view on the role of the state (Alesina and Fuchs-Schündeln, 2007). Empirical studies have also pointed to a significantly different focus of female representatives compared to their male colleagues: Female legislators tend to have different policy priorities and are more likely to express concerns about social policy issues (Thomas, 1994; Seltzer et al., 1997). Hence, gender may be taken as a proxy for the specific policy specialization and, hence, interest for and information on tax issues. Finally, MPs elected directly in a district and not through a party list may have more direct contact with citizens and companies which could be relevant for the perception of globalization constraints. ${ }^{5}$

As pointed out in the introduction personal interests may well influence opinion. For this reason we also experimented with an additional variable that relates to income of legislators other than their uniform compensation for their status as member of parliament. This side income (Nebeneinkünfte) of MPs originates from occupations unrelated to the seat in Bundestag such as self-employment, membership in company supervisory bodies, paid speeches or other. Revenues from these activities are legal for German MPs, but - following a ruling of German's constitutional court in summer 2007 - have to be published. Unfortunately, the publication requirement is limited and requires information about income in three intervals so that the quality of the resulting data is relatively poor. This may explain that an inclusion of a side income variable did not have significant results (not reported), although

\footnotetext{
${ }^{4}$ We owe this insight to the comment of an anonymous referee.

${ }^{5}$ The distinction between the two types of members of parliaments is somewhat blurry in so far as MPs elected via the party list are sometimes candidates in a district and were not elected. We also experimented with a modified party list variable taking account of the relative position of the MP on a party list relative to the maximum number of places on the list which in the election 2005 qualified for a seat in Bundestag (results not reported). This relative position did not prove to be important.
} 
from a theoretical point of view this variable could be a proxy for private interests or information aspects with respect to corporate tax policy.

Finally, we also included basic economic characteristics of the individual MP's federal state in order to allow for special interests related to a constituency's specific needs. State economic characteristics could matter in so far as half of all legislators are elected from state party lists as described in section 2 .

A first look at descriptive statistics allows us to make two interesting observations. First, there is large variation in opinions within most parties for almost all questions. At the same time, however, we observe a strong correlation between ideology measured on the basis of party affiliation and the average answer to the five questions (Table 4). ${ }^{6}$ With the exception of the voter awareness question (Q3), responses to all questions differ by party affiliation. This result may not come as a complete surprise when normative issues such as the desirability of an EU minimum tax on companies is considered. However, the strong correlation of perceived globalization restrictions and ideology is harder to explain and may hint to an ideological bias in information processing, as it has been shown to be virulent in the population at large for the perception of economic issues in general (Blinder and Krueger, 2004; Caplan, 2002). In the following we dig deeper into this question by disentangling the ideological impact on globalization views from other influences related to education, information and the other individual characteristics of Bundestag members.

\section{The formation of tax policy opinions and estimation approach}

The rational formation of tax policy opinions can be described as a two step procedure. In a first step, decision makers collect information on the tax policy environment. With regard to globalization this relates to an assessment of three channels: first, the tax elasticity of real investment $(R I)$, second, the tax elasticity of paper profits $(P P)$ and third, the reaction of voters to tax developments abroad i.e., yardstick competition $(Y C)$. In a second step, decision makers choose the tax policy which maximizes their specific objective function. For example, they vote for minimum taxes $(M)$ or they decide to which extent they stick to an autonomous tax policy $(A)$ even at a cost of increasing outward mobility. This two step approach reflects the common structure of the tax competition models summarized in section 2: Optimization

\footnotetext{
${ }^{6}$ In section 6 we address the link between ideology and party membership in detail.
} 
and, hence, tax policy decisions are based on the existing constraints. However, in contrast to the theoretical tax (competition) literature we now put the assumption of an undistorted consensus on these restrictions to a test. For that purpose, our testing approach focuses on the impact of party ideology (IDE). If - as assumed in the optimum taxation literature - the efficiency costs of taxation are objectively perceived, the awareness of restrictions should not differ among parties. However, ideology should directly influence the second step following conventional theory. Representatives with different subjective equity-efficiency trade-offs should have different tax policy preferences even if they fully agree on the relevance of the three globalization and tax policy channels (e.g., see the standard Meltzer-Richard, 1981, model of redistributive taxation in a closed economy).

The appropriateness of these expectations on the impact of ideology is now tested within the following set-up: To analyze the formation of beliefs on tax policy restrictions under globalization - the first step - models of the following type are considered:

$$
\begin{aligned}
& \text { (1a) } P_{R I}=f_{R I}(E D U, I N F, O I N, S T C, I D E) \\
& \text { (1b) } P_{P P}=f_{P P}(E D U, I N F, O I N, S T C, I D E) \\
& \text { (1c) } P_{Y C}=f_{Y C}(E D U, I N F, O I N, S T C, I D E)
\end{aligned}
$$

The perception $P$ of each of the three channels may be influenced by the individual MP's education $E D U$, his or her availability of objective information $I N F$, other individual characteristics $O I N$, and particular economic characteristics of the legislator's state STC as suggested above. Finally, ideology IDE as a possible additional determinant of perceptions is included.

In a second step the formation of tax policy opinions is finalized by translating the perceived restrictions into preferred policy options, which in turn depend on an individual's objective function. Here we would expect that decision makers with similar perceptions of restrictions should tend to see more room for an autonomous tax policy if they put a relatively large weight on equity relative to efficiency. Similarly, the preference for minimum taxes should not only be influenced by the perceived restrictions but also by ideology because minimum taxes tend to offer more room for redistributive objectives. To test for the relative role of ideology in the second step, models of the following types are considered:

$$
\begin{aligned}
& A=f_{A}\left(P_{R I}, P_{P P}, P_{Y C}, E D U, I N F, \text { OIN }, S T C, I D E\right) \\
& M=f_{M}\left(P_{R M}, P_{P P}, P_{Y C}, E D U, I N F, O I N, S T C, I D E\right)
\end{aligned}
$$


The belief in tax autonomy (A) and the preference for an EU minimum tax (M) are modelled as a function of the perceived restrictions and of ideology directly. The impact of education, influence and other individual characteristics is included in the second step of formation of tax policy positions.

Our survey of the members of the German Bundestag allows us to test for the described structure in the formation of tax policy opinions. We proceed by estimating ordered probit models for the answers Q1-Q3 representing the perceived restrictions according to the first step equations (1a)-(1c). We then continue by analyzing the second step by estimating ordered probit models for the answers to Q4 (related to equation 2a) and Q5 (equation 2b).

Several standard problems of econometric testing of survey data have to be addressed (see Hanson et al., 2005, or Mayda and Rodrik, 2005, for similar approaches): The highly different response rates of different parties point to a selection bias which could influence estimation results. Therefore, we estimate weighted ordered probit models, where weights correct for the sample's lacking representativeness. Our weights are based on two strata of the sample: party membership and years in Bundestag which both are highly significant in a nonresponse analysis. Even these measures cannot exclude that a selection bias can still in principle contaminate the results and we return to this issue in section 6.

Furthermore the descriptive analysis indicates that the variance of answers differs widely between parties. To cope with the resulting problems we allow for party clustered error terms, i.e. the usual assumption of uncorrelated error terms is given up for observations from the same party. As a consequence, our estimation procedure is robust against unobserved variables or structures which lead to a larger homogeneity of answers within one party.

The specification included the proxies for education, information, other individual characteristics and economic structure as they are listed in section 2.

\section{Results}

\section{First step results}

Estimation results for the three first step models reveal a different overall fit of the models (Table 5). Whereas estimations show reasonable properties for the perception of real mobility and profit shifting, the estimation for yardstick competition has hardly any explanatory power. There is support for the relevance of information proxies and less for the importance of educa- 
tion. Economic state characteristics do not show up significantly apart from a weakly significant impact of the unemployment rate in the yardstick competition equation. These results indicate that belief formation on German tax policy is not clearly linked to special interests of a MP's constituency.

Among the information variables memberships in the financial committee responsible for tax policy, the length of Bundestag membership and professional experience as selfemployed lawyer, tax consultant etc. ("Freiberufler") clearly influence the perception of the tax mobility environment. The MPs with a professional background as self-employed tend to stress the importance of paper profit mobility, while they regard real mobility as less important compared to their colleagues among the members of Bundestag. Members of the financial committee who should - with regard to tax policy - be the best informed members of Bundestag tend to stress real mobility as a relevant restriction. The same holds for those MPs with a longer tenure in the Bundestag. The other variables - Eastern/Western German, gender, party list and age - also turn out to be important although to a different degree for the three channels. Female members assess globalization restrictions to be more severe compared to their male colleagues. Eastern German MPs have fewer concerns about profit shifting. Party list MPs assess real mobility and yardstick competition as less pronounced than MPs voted into the parliament directly by a district - a plausible result given the fact that district representatives should have more salient experience with company decision making.

Beyond these detailed findings, however, the essential result is the clear and overwhelming impact of ideology on the perception of globalization restrictions. Thus, the finding of the descriptive data analysis (Table 4) is obviously no statistical artefact and is strongly supported in the multivariate model. Ideology measured on the basis of party membership is not only highly significant: Judged on the size of marginal effects (for each question evaluated at the most frequent answer category) party membership also outweighs the impact of information, education or other variables and these ideological marginal effects are particularly pronounced for real mobility. It is striking that the ordering of party effects for the perception of real mobility corresponds to the left right spectre: Compared to the liberal FDP the parties regard real mobility of companies the less important the further left their political orientation is. Our results strongly reject the hypothesis that ideology is unimportant in the first step of opinion building. Hence, our results challenge the key assumption of standard models of tax policy decision making, in which an objective mobility of tax bases is assumed.

We like to emphasize that the impact of ideology on the perception of constraints can hardly be explained by a MP's incentive to consciously hide his or her true beliefs. First, as 
argued in section 4, individual answers in the underlying survey were confidential so that fears of sanctions for a divergence from official party lines were not warranted. Second, the perception of mobility phenomena as such is hardly an "ideological issue" where a diverging opinion - even if it became public - would pose harm to the individual MP. Note, however, that subconscious mechanisms may well be present and even be a key explanation for our findings. We return to this possibility in our overall conclusions.

Neither are reversed causation problems likely to distort the results to any serious degree. We believe that the perception of tax competition constraints is not crucial for the decision on party membership so that a reversed causation channel should have no major relevance.

\section{Second step results}

The results for the estimation of ordered probit models for answers to Q4 (autonomy) and Q5 (minimum taxes) are presented in Table 6. Based on models (2a) and (2b) we would expect that two classes of variables are important: on the one hand the perceived globalization restrictions and on the other hand individual characteristics linked to a MP's education, information, his or her state's economic characteristics and ideology.

The regression diagnostics show a good fit, as both models show a high share of correct classifications. The first surprising result of the second step results is the loose link between perceived restrictions on the one hand and the perception of tax autonomy and the minimum tax preference on the other hand. Among the three globalization channels only perceived paper profit mobility is significant in both equations. As expected, a larger perceived profit shifting is associated with less autonomy and a larger preference for minimum taxes. Real mobility is weakly significant in the autonomy equation but with a surprising sign: Perception of high real mobility is associated with a more autonomous assessment. Education variables are significant: a degree qualifying for university entry is associated with a perception of less autonomy and less marked preferences for tax harmonization. Interestingly, a university degree increases the perceived autonomy. Information variables have more importance for the view on harmonization than on autonomy. With more years in the Bundestag the preferences for minimum taxes decline. Perhaps not surprisingly, members of the budgetary committee see more autonomy compared to other MPs. Apart from that they are characterized by more scepticism towards EU minimum taxes. Formerly self-employed "Freiberufler" have a stronger tendency to favour minimum taxes. Among the other variables only the Eastern Germany and the party list dummy are significant: MPs directly elected by a district show 
significantly larger sympathy for minimum taxes, representatives from the Eastern part of the country see less autonomy. State characteristics are of importance in the minimum tax model insofar as MPs both from relatively wealthy states and states with high unemployment prefer minimum taxes more than others.

The essential result with respect to the impact of party membership is again its high significance. While the size of marginal effects for party membership in the autonomy equation is comparable to the other types of variables, party affiliation by far outweighs the other in the explanation of tax harmonization preferences. The impact of ideology in the second step is less surprising compared to the first step results because subjective equity-efficiency trade-offs should influence the formation of tax policy opinions for a given perception of restrictions.

\section{Robustness}

We argued above that ideology strongly affects the perception of tax competition channels. However, it is disputable whether party membership in our survey is really a good proxy for ideology. Two kinds of problems have to be discussed, first with respect to the nature of parties and the belief formation within parliamentary party factions and, second, with respect to the technical issue of selection bias in our survey.

\section{Belief formation within a party faction}

For a legislator party membership is a variable representing a complex set of issues. Parties do not only unite politicians with similar ideologies and perceptions, they also impose constraints on their members. For example, Murphy and Shleifer (2004) suggest that parties can be regarded as social networks which allow for an easy influence on opinions of network members. Party members and legislators from a specific party in particular could thus be the victims of party manipulation activities. Thus it is unclear whether the statistical significance of party membership is really the consequence of deeply rooted ideology and resulting psychological process of information filtering or the consequence of party information processes. An example in the context of the German company tax reform is the Social-Democratic finance minister Peer Steinbrück's strategy to cope with resistance in his party and trade unions against tax cuts for companies. In reaction to this he stressed the base broadening elements of the reform 
as a means to fight paper profit mobility ${ }^{7}$. Thus, the argument of high paper profit mobility was highly present in the SPD's reform debate. In this sense, the concern of social-democratic legislators about profit shifting (Table 4, Table 5) could to a certain extent mirror the effect of this information campaign.

Furthermore, the individual MP is heavily dependent on the support of his party for his further career prospects. Hence, the impact of party membership as measured in our analysis may represent phenomena like group dependence, loyalty or information biases and is therefore no undistorted proxy for ideology.

\section{Selection bias}

On a technical level, the identification of ideology on the basis of party membership may be impeded by a selection bias. Highly different response rates between party factions (see Table 1) imply the risk that party membership could simply mirror the effect of hidden variables having an impact on participation in the survey. Therefore, without further checks we cannot be certain that our party membership variable truly reflects ideology.

\subsection{Control group results}

As a first approach to check the importance of both caveats we conducted an identical survey among a control group of economics students at the University of Mannheim in February 2007. In addition to the five questions explained in section 3, students were asked to reveal their party preferences. The survey was conducted anonymously. Obviously, loyalty considerations, political career aspects or specific information networks do not play a role for this control group. Thus, the resulting data allow us to check for the link between ideology and globalization perceptions because party preference is a more unambiguous proxy of ideology than in the case of the Bundestag. Neither a distorting selection bias originating from motives to hide a true position should be present for this control group. As information proxies we included two questions: One for the number of semesters which the student has already been studying economics and a second question whether the student had attended an introductory public finance lecture. Among other individual characteristics the respondents were asked to indicate gender and nationality (German/non-German).

Tables 7 and 8 present the results for the three tax competition channels (model 1a, $1 \mathrm{~b}$ and $1 \mathrm{c}$ ) and the second step regressions (model $2 \mathrm{a}$ and $2 \mathrm{~b}$ ) for the control group. Similar to

\footnotetext{
${ }^{7}$ In a typical statement addressing his party members Steinbrück argues: "Through tax cuts and targeted measures against profit shifting this reform will provide a constant decrease of the fairness gap between profits realized in Germany and profits actually taxed" (Steinbrück, 2007).
} 
the survey among legislators the real mobility and paper profit equations perform better than the yardstick competition equation. Again party association has a highly significant impact on the perception of competition phenomena. For real mobility, even the ordering of the party impact is identical to the Bundestag results: The further left is the party preference the lower is the importance assigned to real mobility. For paper profit mobility the ordering of party effects is quite different however: While for individuals with preference for the SPD the effect is not significantly different from those who favour the liberal FDP (our reference case), students who prefer the other parties perceive less paper profit mobility compared to the FDP supporters. For the Bundestag, the governing parties SPD and CDU/CSU are characterized by a particularly high awareness of paper profit mobility. For the second step results it is striking that perceived restrictions do not appear to be linked at all to the autonomy perception or the preference for minimum taxes. Thus, the surprising result of a weak impact of restrictions relative to ideology in the second step is even reinforced by the control group results.

Taken together the control group results provide reassurance that the key Bundestag results about the impact of ideology in both steps are no statistical artefact caused by either party faction effects or a selection bias in the Bundestag survey. However, the different ordering of party effects in the paper profit equation indicates that the Bundestag party effect is to a certain extent also influenced by specific information processes within the parliament.

\subsection{Party membership and ideology}

As a further robustness test, we replace party dummies by indicators on the ideological position of parties from political science scholars. In their influential study, Benoit and Laver (2006) present programmatic indicators for parties from 47 countries. The indicators are based on interviews with experts who are academics specializing in political parties and electoral politics of his or her country. For the assessment of the German parties interviews from 98 experts were available. The respondents were asked to locate each party on a general left-right scale from 1 (left) to 20 (right) "taking all aspects of party policy into account." While the authors left the precise interpretation of "left" and "right" to the experts, they analysed from further programmatic questions, which dimensions of politics explain these expert judgements. For Germany, the left-right-location is driven by the experts' judgements on parties' positions both in economic and social policy with the latter including positions on abortion, homosexuality and euthanasia. Hence, this indicator can be used as a proxy for a party's overall ideology beyond the narrow field of tax policy. Table 9 summarizes the results for the first 
step regression where the Benoit-Laver-indicator ${ }^{8}$ replaces the party dummies of the Table 5 specifications.

The overwhelming role of ideology for the perception or real mobility is strongly reconfirmed when the left-right indicators with its specific ordering of German parties is imposed: The marginal effect of the Benoit-Laver-indicator amounts to 0.27 for the ideological difference between the Left Party and CDU/CSU and thus is substantially larger than all the significant dummies' marginal effects. Again, the parties further right tend to stress real mobility compared to the parties further left. For the perception of paper profits ideology is highly significant as well but does not clearly outweigh the other significant control variables. This finding supports the view that our party dummies are indeed a useful proxy of ideology and that the stipulated ideology effect not merely reflects other partisan effects (constraints on party members, biased information within party networks and the like). Note that the signs of control variables remain robust even though some lose (party list and age for real mobility, financial committee for yardstick competition) or gain (female and party list for paper profit mobility) significance.

\section{Conclusion}

To the best of our knowledge this is the first paper to survey the opinions of policy makers with respect to tax policy at a time of increasing international integration. Policy makers are an interesting group to consider, as they actually vote on policies directly and probably are better informed than average citizens. The survey of German legislators was done at a time when tax policy reform was high on the agenda and a few months after the survey the Bundestag actually voted on a reform bill that will lower the statutory and effective tax rates on companies in Germany. The main finding of our analysis is the identification of a strong ideological bias in the legislators' views on the interaction between globalization and tax policy. This suggests that the perceived efficiency costs of taxation in open economies differ systematically across political ideologies.

Our results are also interesting from a comparative politics perspective. Germany is a parliamentary democracy in which party discipline is strong and the candidate selection process is heavily regulated by the constitution and party law. Our survey sheds light on how much variation in opinions among legislators within a party exists. Party discipline seems to

\footnotetext{
${ }^{8}$ The left-right scores for the Bundestag parties from Benoit and Laver (2006) are as follows: Left Party 3.6, Greens 7.1, SPD 8.4, FDP 13.4, CDU/CSU 13.6.
} 
work quite well given the fairly uniform voting behaviour along party lines on the actual tax reform bill relative to the wide variation of opinions in our survey.

One caveat is important. At this point we are unable to identify the precise mechanism which is responsible for the strong impact of ideology. The insights from the perception of paper profit shifting indicate that specific information networks or campaigns could have an impact in shaping party members views. An alternative channel could originate from the characteristics which are typical for the successful career of party members up to winning a seat in Parliament. It may well be the case that only individuals who are subject to the same biases as their fellow party members and their party's electorate will be able to climb the party career ladder. Both economic and psychological approaches exist which help to specifiy these types of biasing group mechanisms. In his economic theory of religious knowledge, Hardin (1997) describes a mechanism of religious belief formation which may equally be relevant in the context of belief formation on economic facts in a political group: If belief $\mathrm{x}$ dominates in a certain group it will be in the interest of the group's individual members to profess belief in $\mathrm{x}$ in order to enjoy the acceptance of the group. As a consequence of communication within this group a member receives information which will tend to reconfirm this group belief. Even a member who initially only pretended to hold a certain belief in order to safeguard his position in the group will perceive a growing body of (group) evidence that this belief is the true one. Thus even biased beliefs can be stable. The classical psychological approach would be an application of the theory of cognitive dissonance (Festinger, 1957): Individuals only tend to correct their beliefs if the negative feelings (i.e. the cognitive dissonance) resulting from the contradiction between prior beliefs and perceived evidence becomes too strong. The information networks of a political party with their ideological biases shield their members from information contradicting their political views. Hence, party memberships may help to stick to beliefs which are in an obvious contrast to the evidence which is available to non-members. In the context of our survey this can explain why political preferences e.g. on the desirable distributive role of corporate taxation can feed back into the perception of restrictions from tax competition. Therefore, what may be new to neoclassical models of tax competition will hardly come as a surprise from a psychological point of view.

Future research should attempt to overcome our incomplete understanding of the process which drives the formations of perceptions on globalization constraints. One way to tackle the issue is to get more information from the policy makers themselves, for example, by asking them how they form their opinion. We did not pursue this possibility with the legislators from the German Bundestag, as it proved fairly difficult to get them to answer just our six 
questions. We expect more willingness to participate when policy makers from lower level of governments are surveyed. In this context future research should survey policy makers from competing jurisdictions and compare their perceived degree of competition with estimates from a strategic interaction model where actual tax rates are the key endogenous variables. This approach would allow to find independent confirmation for or modification of existing theories of fiscal competition.

\section{References}

Alesina, A. and G.-M. Angeletos (2005). "Fairness and Redistribution", $\underline{\text { American Economic }}$ Review 95(4), 960-980.

Alesina, A. and N. Fuchs-Schündeln (2007). "Good bye Lenin (or not?): The Effect of Communism on People`s Preferences”, American Economic Review 97(4), 1507-1528.

Ashworth, J. S. and B. Heyndels (1997). "Politicians' Preferences on Local Tax Rates: An Empirical analysis", European Journal of Political Economy 13, 479-502.

Ashworth, J. S. and B. Heyndels (2000). "Politicians' Opinions on Tax Reforms", Public Choice 103, 117-138.

Bénabou, Roland (2008). “Ideology”, NBER Working Paper 13907.

Bénabou, Roland and J. Tirole (2006). "Belief in a Just World and Redistribution Politics", Quarterly Journal of Economics 112(2), 699-746.

Benoit, K. and M. Laver (2006). "Party Policy in Modern Democracies”, Routledge.

Besley, T. and A. Case (1995). "Incumbent Behavior: Vote Seeking, tax setting and yardstick competition", American Economic Review 85, 25-45.

Birney, M., M.J. Graetz, and I. Shapior (2006). "Public Opinion and the Push to Repeal the Estate Tax", National Tax Journal 59(3), 439-461.

Blinder, A. S. and A. Krueger (2004). "What Does the Public Know about Economic Policy, and How Does It Know It?", Brookings Papers on Economic Activity (1:2004), 327397.

Caplan, B. (2002). "Systematically Biased Beliefs about Economics: Robust Evidence of Judgemental Anomalies from the Survey of Americans and Economists on the Economy", The Economic Journal 112: 1-26.

Caplan, B. (2007). „The Myth of the Rational Voter: Why Democracies Choose Bad Policies", Princeton University Press.

Deutscher Bundestag (2007a). „Entwurf eines Unternehmensteuerreformgesetzes 2008“, Drucksache 16/4841, March 27, 2007.

Deutscher Bundestag (2007b). „Stenografischer Bericht der 101. Sitzung vom 25. Mai 2007”, Plenarprotokoll 16/101.

Devereux, M. B., R. Griffith and A. Klemm. (2002). "Corporate income tax reforms and international tax competition”, Economic Policy 35, 449-496. 
Festinger, L. (1957). “A Theory of Cognitive Dissonance”, Stanford University Press, Stanford.

Hanson, G. H., K. F. Scheve and M. Slaughter (2005). "Public finance and individual preferences over globalization strategies", NBER Working Paper No. 11028.

Hardin, R. (1997). "The Economics of Religious Beliefs", Journal of Institutional and Theoretical Economics 153, 259-284.

Haufler, A. (2006). „Die Besteuerung multinationaler Unternehmen“, University of Munich, Discussion Paper 2006-21.

Haufler, A. and G. Schjelderup (2000). "Corporate Tax Systems and Cross Country Profit Shifting”, Oxford Economic Papers 52, 306-325.

Krupnikov, Y., A.S. Levine, A. Lupia, and P. Markus (2006). "Public Ignorance and Estate Tax Repeal: The Effect of Partisan Differences and Survey Incentives", National Tax Journal 59(3), 425-437.

Mayda, A. M. and D. Rodrik (2005). "Why are some people (and countries) more protectionist than others?", European Economic Review 49: 1393-1430.

Meltzer, A. and S. Richard (1981). "A rational theory of the size of government", Journal of Political Economy 89, 914-927.

Mintz, J. and M. Smart (2004). "Income shifting, investment, and tax competition: theory and evidence from provincial taxation in Canada”, Journal of Public Economics 88, 11491168.

Murphy, K.M. and A. Shleifer (2004). "Persuasion in Politics", American Economic Review, Papers and Proceedings, 94(2), 435-439.

Poguntke, T. (1994). "Parties in a Legalistic Culture: The Case of Germany", in R.S. Katz and P. Mair: How Parties Organize, Sage Publications, London, 185-215.

Roberts, G. (1988). "The German Federal Republic: the two-lane route to Bonn", in M. Gallagher and M. Marsh: Candidate Selection in Comparative Perspective, Sage Publications, London, 94-118.

Seltzer, R.A., J. Newman and M. Voorhees Leighton (1997). "Sex as a political variable: Women as candidates and voters in U.S. elections", Lynne Rienner Publishers Inc.

Slemrod, J. (2003). "The role of misconceptions in support of regressive tax reform", University of Michigan, November 3, 2003.

Steinbrück, P. (2007). "In Deutschland investieren“, Communication on the SPD Website, 30.03.2007, www.spd.de/menu/1710203/.

Stratmann, T. and M. Baur (2002). „Plurality Rule, Proportional Representation, and the German Bundestag: How Incentives to Pork-Barrel Differ Across Electoral Systems“, American Journal of Political Science 46, 506-514.

Thomas, S. (1994). "How women legislate", Oxford University Press, New York.

Wilson, J.D. (1986). „A Theory of Interregional Tax Competition“, Journal of Urban Economics $19,296-315$.

Wilson, J.D. (1999). “Theories of Tax Competition”, National Tax Journal 52, 269-304.

Zodrow, G. and P. Mieszkowski (1986). "Pigou, Tiebout, property taxation and the underprovision of local public goods", Journal of Urban Economics 19, 356-370. 
Table 1: Response rate by party in the Bundestag

\begin{tabular}{|l|c|c|c|}
\hline Party & Number of seats & Responses & Response rate \\
\hline CDU/CSU & 225 & 53 & 23,56 \\
\hline SPD & 222 & 33 & 14,86 \\
\hline FDP & 61 & 32 & 52,46 \\
\hline Left Party & 53 & 27 & 50,94 \\
\hline Alliance 90/The Greens & 51 & 12 & 23,53 \\
\hline Members without fraction & 2 & 0 & 0,00 \\
\hline Total & 614 & 157 & 25,57 \\
\hline
\end{tabular}

Table 2: Variable definitions

\begin{tabular}{|c|c|c|}
\hline Variable & Unit & Explanations \\
\hline \multicolumn{3}{|r|}{ Education variables } \\
\hline Abitur & Dummy & Secondary qualification for university entrance \\
\hline Tertiary degree & Dummy & Degree from university or polytechnic \\
\hline \multicolumn{3}{|c|}{ Proxies for degree of information and experience } \\
\hline Economics/business & Dummy & Tertiary education in business administration or economics \\
\hline $\begin{array}{l}\text { Self-employed } \\
\text { "Freiberufler" }\end{array}$ & Dummy & $\begin{array}{l}\text { Last professional position as an independent lawyer, tax } \\
\text { advisor or in a similar self-employed occupation }\end{array}$ \\
\hline Years in Bundestag & $\begin{array}{l}\text { Discrete } \\
\text { variable }\end{array}$ & $\begin{array}{l}\text { Calculated as } 2007 \text { minus year of Bundestag entry, interrup- } \\
\text { tions are taken into account }\end{array}$ \\
\hline $\begin{array}{l}\text { Member financial } \\
\text { committee }\end{array}$ & Dummy & Deals with tax policy, financial markets, monetary policy \\
\hline $\begin{array}{l}\text { Member budget com- } \\
\text { mittee }\end{array}$ & Dummy & $\begin{array}{l}\text { Deals with federal government budget, in particular expendi- } \\
\text { ture side }\end{array}$ \\
\hline \multicolumn{3}{|r|}{ Other variables } \\
\hline Eastern Germany & Dummy & $\begin{array}{l}\text { Member of parliament from a district or a party list in Eastern } \\
\text { Germany }\end{array}$ \\
\hline Female & Dummy & \\
\hline Party list & Dummy & $\begin{array}{l}\text { Not elected directly from a district but qualified for Bundestag } \\
\text { by position on a party list }\end{array}$ \\
\hline Age & $\begin{array}{l}\text { Discrete } \\
\text { variable }\end{array}$ & Calculated as 2007 minus year of birth \\
\hline \multicolumn{3}{|r|}{ State characteristics } \\
\hline Unemployment rate & $\begin{array}{l}\text { Continuous } \\
\text { variable }\end{array}$ & in \% for the year 2006, source: German Statistical Office \\
\hline GDP per capita & $\begin{array}{l}\text { Continuous } \\
\text { variable }\end{array}$ & In Euro for the year 2006, source: German Statistical Office \\
\hline
\end{tabular}

Sources: Bundestag if no other source is named. 
Table 3: Descriptive Statistics

\begin{tabular}{|l|l|r|r|r|r|r|}
\hline Variable & Unit & \multicolumn{1}{l|}{ Mean } & \multicolumn{1}{l|}{$\begin{array}{l}\text { Std. } \\
\text { Dev. }\end{array}$} & \multicolumn{1}{l|}{ Min } & \multicolumn{1}{l|}{ Max } \\
\hline \multicolumn{7}{|c|}{ Education variables } \\
\hline Abitur & Dummy & 0.80 & 0.40 & 0 & 1 \\
\hline Tertiary degree & Dummy & 0.86 & 0.35 & 0 & 1 \\
\hline \multicolumn{7}{|c|}{ Proxies for degree of information and experience } \\
\hline Economics/business & Dummy & 0.22 & 0.42 & 0 & 1 \\
\hline $\begin{array}{l}\text { Self-employed } \\
\text { "Freiberufler" }\end{array}$ & Dummy & 0.16 & 0.37 & 0 & 1 \\
\hline Years in Bundestag & Years & 6.78 & 5.45 & 1 & 27 \\
\hline $\begin{array}{l}\text { Member financial } \\
\text { committee }\end{array}$ & Dummy & 0.18 & 0.39 & 0 & 1 \\
\hline $\begin{array}{l}\text { Member budget com- } \\
\text { mittee }\end{array}$ & Dummy & 0.17 & 0.38 & 0 & 1 \\
\hline \multicolumn{7}{|c|}{ Other variables } \\
\hline Eastern Germany & Dummy & 0.21 & 0.41 & 0 & 1 \\
\hline Female & Dummy & 0.33 & 0.47 & 0 & 1 \\
\hline Party list & Dummy & 0.64 & 0.48 & 0 & 1 \\
\hline Age & Years & 49.82 & 9.77 & 23 & 69 \\
\hline \multicolumn{7}{|l|}{ State characteristics } \\
\hline Unemployment rate & \% & 10.7 & 4.2 & 6.3 & 19.0 \\
\hline GDP per capita & $\begin{array}{l}\text { Euro } \\
2006\end{array}$ & 27,529 & 5,427 & 19,112 & 49,318 \\
\hline
\end{tabular}


Table 4: Survey results by party membership

\begin{tabular}{|c|c|c|c|c|c|}
\hline & Observations & Mean & Std. Dev. & Min & $\operatorname{Max}$ \\
\hline \multicolumn{6}{|c|}{ Q1 Real corporate mobility } \\
\hline FDP & 32 & 7.41 & 1.36 & 3 & 9 \\
\hline CDU/CSU & 53 & 6.68 & 1.48 & 3 & 9 \\
\hline SPD & 33 & 5.76 & 1.52 & 2 & 9 \\
\hline Greens & 12 & 4.67 & 1.50 & 3 & 8 \\
\hline Left Party & 27 & 3.93 & 1.47 & 2 & 8 \\
\hline Total & 157 & 6.01 & 1.88 & 2 & 9 \\
\hline \multicolumn{6}{|c|}{ Anova, F-Test p-value: 0.000} \\
\hline \multicolumn{6}{|c|}{ Q2 Profit shifting } \\
\hline FDP & 31 & 5.81 & 1.60 & 3 & 8 \\
\hline $\mathrm{CDU} / \mathrm{CSU}$ & 53 & 6.21 & 1.54 & 3 & 9 \\
\hline SPD & 33 & 7.55 & 1.52 & 2 & 9 \\
\hline Greens & 12 & 7.00 & 1.04 & 5 & 8 \\
\hline Left Party & 27 & 7.07 & 1.88 & 3 & 9 \\
\hline Total & 156 & 6.62 & 1.69 & 2 & 9 \\
\hline \multicolumn{6}{|c|}{ Anova, F-Test p-value: 0.000} \\
\hline \multicolumn{6}{|c|}{ Q3 Voter awareness } \\
\hline FDP & 32 & 4.50 & 2.66 & 1 & 9 \\
\hline CDU/CSU & 53 & 4.25 & 1.95 & 1 & 9 \\
\hline SPD & 33 & 3.55 & 1.94 & 1 & 8 \\
\hline Greens & 12 & 4.08 & 2.07 & 1 & 7 \\
\hline Left Party & 27 & 4.19 & 1.78 & 1 & 7 \\
\hline Total & 157 & 4.13 & 2.09 & 1 & 9 \\
\hline \multicolumn{6}{|c|}{ Anova, F-Test p-value: 0.444} \\
\hline \multicolumn{6}{|c|}{ Q4 National autonomy } \\
\hline FDP & 32 & 6.53 & 1.67 & 2 & 9 \\
\hline CDU/CSU & 53 & 6.72 & 1.56 & 3 & 9 \\
\hline SPD & 33 & 5.94 & 1.20 & 3 & 7 \\
\hline Greens & 12 & 6.50 & 0.67 & 6 & 8 \\
\hline Left Party & 27 & 7.37 & 1.71 & 2 & 9 \\
\hline Total & 157 & 6.61 & 1.54 & 2 & 9 \\
\hline \multicolumn{6}{|c|}{ Anova, F-Test p-value: 0.009} \\
\hline \multicolumn{6}{|c|}{ Q5 EU minimum taxes } \\
\hline FDP & 32 & 2.50 & 2.36 & 1 & 8 \\
\hline CDU/CSU & 52 & 4.48 & 2.75 & 1 & 9 \\
\hline SPD & 33 & 7.82 & 1.76 & 3 & 9 \\
\hline Greens & 12 & 7.33 & 1.07 & 5 & 9 \\
\hline Left Party & 26 & 8.35 & 0.98 & 6 & 9 \\
\hline Total & 155 & 5.65 & 3.08 & 1 & 9 \\
\hline \multicolumn{6}{|c|}{ Anova, F-Test p-value: 0.000} \\
\hline \multicolumn{6}{|c|}{ Q6 Equity } \\
\hline FDP & 32 & 5.38 & 2.04 & 1 & 9 \\
\hline CDU/CSU & 52 & 6.81 & 1.63 & 3 & 9 \\
\hline SPD & 33 & 7.61 & 1.64 & 3 & 9 \\
\hline Greens & 12 & 7.67 & 1.07 & 6 & 9 \\
\hline Left Party & 27 & 8.59 & 0.64 & 7 & 9 \\
\hline Total & 156 & 7.06 & 1.88 & 1 & 9 \\
\hline \multicolumn{6}{|c|}{ Anova, F-Test p-value: 0.000} \\
\hline
\end{tabular}


Table 5: Ordered probit estimation: Tax policy restrictions

\begin{tabular}{|c|c|c|c|c|c|c|}
\hline \multirow[b]{2}{*}{ Variable } & \multicolumn{2}{|c|}{$\begin{array}{c}\text { Q1: Mobility real } \\
\text { capital } \\
\text { Model 1a }\end{array}$} & \multicolumn{2}{|c|}{$\begin{array}{c}\text { Q2: Mobility paper prof- } \\
\text { its } \\
\text { Model 1b }\end{array}$} & \multicolumn{2}{|c|}{$\begin{array}{l}\text { Q3: Yardstick } \\
\text { competition } \\
\text { Model 1c }\end{array}$} \\
\hline & Coefficient & $\begin{array}{c}\text { Marginal } \\
\text { effect }^{\star}\end{array}$ & Coefficient & $\begin{array}{c}\text { Marginal } \\
\text { effect }^{\star}\end{array}$ & Coefficient & $\begin{array}{c}\text { Marginal } \\
\text { effect }^{*}\end{array}$ \\
\hline \multicolumn{7}{|c|}{ Education } \\
\hline Secondary (“Abitur”) & $\begin{array}{l}0.363^{* *} \\
(0.156) \\
\end{array}$ & 0.053 & $\begin{array}{c}0.237 \\
(0.306) \\
\end{array}$ & 0.007 & $\begin{array}{c}0.055 \\
(0.215) \\
\end{array}$ & -0.013 \\
\hline Tertiary & $\begin{array}{c}0.135 \\
(0.216)\end{array}$ & 0.019 & $\begin{array}{l}-0.222 \\
(0.594)\end{array}$ & 0.003 & $\begin{array}{l}-0.228 \\
(0.231)\end{array}$ & 0.053 \\
\hline \multicolumn{7}{|c|}{ Information } \\
\hline Economic/business & $\begin{array}{l}-0.145 \\
(0.461) \\
\end{array}$ & -0.020 & $\begin{array}{l}-0.181 \\
(0.139) \\
\end{array}$ & -0.004 & $\begin{array}{l}-0.036 \\
(0.255) \\
\end{array}$ & 0.008 \\
\hline "Freiberufler" & $\begin{array}{l}-0.373^{* * *} \\
(0.129) \\
\end{array}$ & -0.055 & $\begin{array}{l}0.394^{* * *} \\
(0.135) \\
\end{array}$ & -0.012 & $\begin{array}{l}0.263^{* *} \\
(0.134) \\
\end{array}$ & -0.061 \\
\hline Years in Bundestag & $\begin{array}{l}0.055^{\star \star \star} \\
(0.014)\end{array}$ & 0.007 & $\begin{array}{l}-0.042^{\star \star \star} \\
(0.011)\end{array}$ & 0.000 & $\begin{array}{l}-0.003 \\
(0.016)\end{array}$ & 0.001 \\
\hline $\begin{array}{l}\text { Member financial commit- } \\
\text { tee }\end{array}$ & $\begin{array}{l}0.457^{* \star \star} \\
(0.127)\end{array}$ & 0.051 & $\begin{array}{l}-0.107 \\
(0.160)\end{array}$ & -0.002 & $\begin{array}{l}0.182^{*} \\
(0.109) \\
\end{array}$ & -0.043 \\
\hline Member budget committee & $\begin{array}{l}-0.300 \\
(0.261) \\
\end{array}$ & -0.043 & $\begin{array}{c}0.341 \\
(0.392) \\
\end{array}$ & -0.008 & $\begin{array}{l}-0.030 \\
(0.140) \\
\end{array}$ & 0.007 \\
\hline \multicolumn{7}{|c|}{ Other individual characteristics } \\
\hline Eastern Germany & $\begin{array}{c}0.301 \\
(0.241)\end{array}$ & 0.037 & $\begin{array}{c}-0.779^{\star \star \star} \\
(0.200)\end{array}$ & -0.061 & $\begin{array}{l}0.688^{* * *} \\
(0.221)\end{array}$ & -0.150 \\
\hline Female & $\begin{array}{l}0.583^{\star \star \star} \\
(0.203)\end{array}$ & 0.067 & $\begin{array}{c}0.273 \\
(0.169) \\
\end{array}$ & -0.002 & $\begin{array}{c}0.157 \\
(0.161) \\
\end{array}$ & -0.037 \\
\hline Party list & $\begin{array}{l}-0.283^{\star *} \\
(0.116)\end{array}$ & -0.038 & $\begin{array}{l}-0.062 \\
(0.098) \\
\end{array}$ & -0.001 & $\begin{array}{l}-0.439^{* *} \\
(0.203)\end{array}$ & 0.102 \\
\hline Age & $\begin{array}{l}-0.016^{\star *} \\
(0.008)\end{array}$ & -0.002 & $\begin{array}{c}0.006 \\
(0.007)\end{array}$ & 0.000 & $\begin{array}{c}0.004 \\
(0.008)\end{array}$ & -0.001 \\
\hline \multicolumn{7}{|c|}{ State characteristics } \\
\hline Unemployment rate & $\begin{array}{c}0.020 \\
(0.023) \\
\end{array}$ & 0.003 & $\begin{array}{c}0.101 \\
(0.078) \\
\end{array}$ & 0.001 & $\begin{array}{l}-0.060^{\star} \\
(0.036) \\
\end{array}$ & 0.014 \\
\hline GDP per capita & $\begin{array}{c}0.000 \\
(0.000) \\
\end{array}$ & 0.000 & $\begin{array}{c}0.000 \\
(0.000) \\
\end{array}$ & 0.000 & $\begin{array}{c}0.000 \\
(0.000) \\
\end{array}$ & 0.000 \\
\hline \multicolumn{7}{|c|}{ Party } \\
\hline CDU/CSU & $\begin{array}{l}-0.795^{\star \star \star} \\
(0.076)\end{array}$ & -0.110 & $\begin{array}{c}0.170 \\
(0.169)\end{array}$ & 0.000 & $\begin{array}{l}-0.276^{\star *} \\
(0.108)\end{array}$ & 0.065 \\
\hline SPD & $\begin{array}{l}-1.522^{\star \star \star} \\
(0.156)\end{array}$ & -0.190 & $\begin{array}{l}1.155^{\star * *} \\
(0.226)\end{array}$ & -0.036 & $\begin{array}{l}-0.656^{\star * *} \\
(0.101)\end{array}$ & 0.149 \\
\hline GREENS & $\begin{array}{l}-2.215^{\star \star *} \\
(0.128) \\
\end{array}$ & -0.235 & $\begin{array}{l}0.501^{* * *} \\
(0.094)\end{array}$ & -0.025 & $\begin{array}{l}-0.363^{* \star *} \\
(0.102) \\
\end{array}$ & 0.083 \\
\hline LEFT PARTY & $\begin{array}{l}-2.856^{\star \star \star} \\
(0.274)\end{array}$ & -0.248 & $\begin{array}{l}1.019^{\star \star \star} \\
(0.247)\end{array}$ & -0.096 & $\begin{array}{l}-0.034 \\
(0.209)\end{array}$ & 0.008 \\
\hline \multicolumn{7}{|c|}{ Regression diagnostics } \\
\hline $\begin{array}{l}p \text {-value joint significance } \\
\text { of variables }\end{array}$ & \multicolumn{2}{|c|}{0.000} & \multicolumn{2}{|c|}{0.068} & \multicolumn{2}{|c|}{0.000} \\
\hline $\begin{array}{l}\text { p-value joint significance } \\
\text { party dummies }\end{array}$ & \multicolumn{2}{|c|}{0.000} & \multicolumn{2}{|c|}{0.000} & \multicolumn{2}{|c|}{0.000} \\
\hline Observations & \multicolumn{2}{|c|}{157} & \multicolumn{2}{|c|}{156} & \multicolumn{2}{|c|}{157} \\
\hline $\begin{array}{l}\text { Share correct } \\
\text { classifications } \\
\text { (exact hit/absolute classifi- } \\
\text { cation error }<=1 \text { ) }\end{array}$ & \multicolumn{2}{|c|}{$0.261 / 0.745$} & \multicolumn{2}{|c|}{$0.244 / 0.718$} & \multicolumn{2}{|c|}{$0.204 / 0.484$} \\
\hline Pseudo-R2 & \multicolumn{2}{|c|}{0.130} & \multicolumn{2}{|c|}{0.090} & \multicolumn{2}{|c|}{0.026} \\
\hline
\end{tabular}

Party: FDP (liberal party) dummy not included; *marginal effect at mode (Q1: 7, Q2: 7, Q3: 2);

$* / * * * * *$ : significant at $10 / 5 / 1$ percent level. 
Table 6: Ordered probit estimation: Tax policy

\begin{tabular}{|c|c|c|c|c|}
\hline \multirow[b]{2}{*}{ Variable } & \multicolumn{2}{|c|}{$\begin{array}{l}\text { Q4: Autonomy of tax policy } \\
\text { Model } 2 a\end{array}$} & \multicolumn{2}{|c|}{$\begin{array}{l}\text { Q5: Preference minimum taxes } \\
\text { Model } 2 \mathrm{~b}\end{array}$} \\
\hline & Coefficient & Marginal effect ${ }^{\star}$ & Coefficient & Marginal effect ${ }^{\star}$ \\
\hline \multicolumn{5}{|c|}{ Perceived restrictions } \\
\hline Real mobility (Q1) & $\begin{array}{l}0.196^{*} \\
(0.113) \\
\end{array}$ & 0.025 & $\begin{array}{l}-0.100 \\
(0.062) \\
\end{array}$ & -0.025 \\
\hline Paper profits (Q2) & $\begin{array}{l}-0.073^{\star \star} \\
(0.033)\end{array}$ & -0.009 & $\begin{array}{l}0.177^{\star *} \\
(0.089)\end{array}$ & 0.044 \\
\hline Yardstick (Q3) & $\begin{array}{c}0.012 \\
(0.052)\end{array}$ & 0.002 & $\begin{array}{l}-0.045 \\
(0.071)\end{array}$ & -0.011 \\
\hline \multicolumn{5}{|c|}{ Education } \\
\hline Secondary (“Abitur”) & $\begin{array}{l}-0.414^{* * *} \\
(0.150) \\
\end{array}$ & -0.036 & $\begin{array}{l}-0.442^{*} \\
(0.232) \\
\end{array}$ & -0.123 \\
\hline Tertiary & $\begin{array}{l}0.669^{\star \star \star} \\
(0.150)\end{array}$ & 0.123 & $\begin{array}{l}-0.130 \\
(0.407) \\
\end{array}$ & -0.034 \\
\hline \multicolumn{5}{|c|}{ Information } \\
\hline Economic/business & $\begin{array}{c}0.185 \\
(0.158)\end{array}$ & 0.021 & $\begin{array}{c}0.007 \\
(0.230)\end{array}$ & 0.002 \\
\hline "Freiberufler" & $\begin{array}{c}0.143 \\
(0.267) \\
\end{array}$ & 0.016 & $\begin{array}{l}0.382^{* \star *} \\
(0.086)\end{array}$ & 0.107 \\
\hline Years in Bundestag & $\begin{array}{l}-0.031 \\
(0.025) \\
\end{array}$ & -0.004 & $\begin{array}{l}-0.040^{\star *} \\
(0.016) \\
\end{array}$ & -0.010 \\
\hline $\begin{array}{l}\text { Member financial } \\
\text { committee }\end{array}$ & $\begin{array}{c}0.168 \\
(0.283) \\
\end{array}$ & 0.019 & $\begin{array}{l}-0.229 \\
(0.223) \\
\end{array}$ & -0.053 \\
\hline Member budget committee & $\begin{array}{l}0.245^{\star} \\
(0.139) \\
\end{array}$ & 0.025 & $\begin{array}{l}-0.404^{*} \\
(0.220) \\
\end{array}$ & -0.088 \\
\hline \multicolumn{5}{|c|}{ Other individual characteristics } \\
\hline Eastern Germany & $\begin{array}{l}-0.403^{*} \\
(0.220) \\
\end{array}$ & -0.067 & $\begin{array}{l}-0.046 \\
(0.318) \\
\end{array}$ & -0.011 \\
\hline Female & $\begin{array}{l}-0.022 \\
(0.162) \\
\end{array}$ & -0.003 & $\begin{array}{l}-0.178 \\
(0.119) \\
\end{array}$ & -0.043 \\
\hline Party list & $\begin{array}{l}-0.012 \\
(0.284) \\
\end{array}$ & -0.002 & $\begin{array}{l}-0.584^{\star * \star} \\
(0.137)\end{array}$ & -0.148 \\
\hline Age & $\begin{array}{c}0.009 \\
(0.014) \\
\end{array}$ & 0.001 & $\begin{array}{c}0.019 \\
(0.014) \\
\end{array}$ & 0.005 \\
\hline \multicolumn{5}{|c|}{ State characteristics } \\
\hline Unemployment rate & $\begin{array}{c}0.071 \\
(0.059)\end{array}$ & 0.009 & $\begin{array}{l}0.113^{*} \\
(0.068)\end{array}$ & 0.028 \\
\hline GDP per capita & $\begin{array}{c}0.000 \\
(0.000) \\
\end{array}$ & 0.000 & $\begin{array}{l}0.000^{* *} \\
(0.000)\end{array}$ & 0.000 \\
\hline \multicolumn{5}{|c|}{ Party } \\
\hline CDU/CSU & $\begin{array}{l}0.362^{*} \\
(0.204) \\
\end{array}$ & 0.040 & $\begin{array}{l}0.563^{\star \star \star} \\
(0.113)\end{array}$ & 0.150 \\
\hline SPD & $\begin{array}{c}0.013 \\
(0.177) \\
\end{array}$ & 0.002 & $\begin{array}{l}2.038^{\star * *} \\
(0.115)\end{array}$ & 0.582 \\
\hline GREENS & $\begin{array}{c}0.438 \\
(0.379) \\
\end{array}$ & 0.028 & $\begin{array}{l}1.835^{\star \star *} \\
(0.266)\end{array}$ & 0.630 \\
\hline LEFT PARTY & $\begin{array}{l}1.460^{\star \star \star} \\
(0.344)\end{array}$ & -0.107 & $\begin{array}{l}2.666^{\star \star *} \\
(0.244)\end{array}$ & 0.814 \\
\hline \multicolumn{5}{|c|}{ Regression diagnostics } \\
\hline $\begin{array}{l}\mathrm{p} \text {-value joint significance } \\
\text { of variables }\end{array}$ & \multicolumn{2}{|c|}{0.000} & \multicolumn{2}{|c|}{0.000} \\
\hline $\begin{array}{l}p \text {-value joint significance } \\
\text { party dummies }\end{array}$ & \multicolumn{2}{|c|}{0.000} & \multicolumn{2}{|c|}{0.000} \\
\hline Observations & \multicolumn{2}{|c|}{156} & \multicolumn{2}{|c|}{154} \\
\hline $\begin{array}{l}\text { Share correct classifications } \\
\text { (exact hit/absolute classifi- } \\
\text { cation error }<=1 \text { ) }\end{array}$ & \multicolumn{2}{|c|}{$0.376 / 0.732$} & \multicolumn{2}{|c|}{$0.413 / 0.671$} \\
\hline Pseudo-R2 & \multicolumn{2}{|c|}{0.081} & \multicolumn{2}{|c|}{0.208} \\
\hline
\end{tabular}

Party: FDP (liberal party) dummy not included; *marginal effect at mode (Q4: 7, Q5: 9); ${ }^{*} /{ }^{* * \star *}$ : significant at $10 / 5 / 1$ percent level. 
Table 7: Ordered probit estimation control group: Tax policy restrictions

\begin{tabular}{|c|c|c|c|c|c|c|}
\hline \multirow[b]{2}{*}{ Variable } & \multicolumn{2}{|c|}{$\begin{array}{c}\text { Q1: Mobility real } \\
\text { capital } \\
\text { Model 1a }\end{array}$} & \multicolumn{2}{|c|}{$\begin{array}{l}\text { Q2: Mobility paper } \\
\text { profits } \\
\text { Model 1b }\end{array}$} & \multicolumn{2}{|c|}{$\begin{array}{l}\text { Q3: Yardstick } \\
\text { competition } \\
\text { Model 1c }\end{array}$} \\
\hline & Coefficient & $\begin{array}{c}\text { Marginal } \\
\text { effect }^{\star}\end{array}$ & Coefficient & $\begin{array}{c}\text { Marginal } \\
\text { effect }^{*}\end{array}$ & Coefficient & $\begin{array}{c}\text { Marginal } \\
\text { effect }^{*}\end{array}$ \\
\hline \multicolumn{7}{|c|}{ Information } \\
\hline Public finance lecture & $\begin{array}{l}-0.341 \\
(0.288) \\
\end{array}$ & 0.026 & $\begin{array}{c}-0.891^{\star \star \star} \\
(0.185) \\
\end{array}$ & 0.039 & $\begin{array}{l}-0.208 \\
(0.285) \\
\end{array}$ & 0.027 \\
\hline Number of semesters & $\begin{array}{l}0.234^{\star \star} \\
(0.098)\end{array}$ & -0.015 & $\begin{array}{c}0.083 \\
(0.100) \\
\end{array}$ & -0.001 & $\begin{array}{c}0.150 \\
(0.166) \\
\end{array}$ & -0.019 \\
\hline \multicolumn{7}{|c|}{ Other individual characteristics } \\
\hline German & $\begin{array}{c}0.117 \\
(0.293) \\
\end{array}$ & -0.006 & $\begin{array}{c}0.276 \\
(0.171) \\
\end{array}$ & 0.203 & $\begin{array}{l}-0.021 \\
(0.530) \\
\end{array}$ & 0.702 \\
\hline Female & $\begin{array}{l}0.559^{*} \\
(0.312)\end{array}$ & -0.054 & $\begin{array}{c}0.291^{\star \star \star} \\
(0.111)\end{array}$ & $0.413^{\star * \star}$ & $\begin{array}{c}-0.057^{\star \star *} \\
(0.109)\end{array}$ & 0.000 \\
\hline \multicolumn{7}{|c|}{ Party } \\
\hline CDU/CSU & $\begin{array}{l}-0.192^{* *} \\
(0.086)\end{array}$ & 0.009 & $\begin{array}{c}-0.489^{* * *} \\
(0.103)\end{array}$ & -0.014 & $\begin{array}{c}0.197 \\
(0.185)\end{array}$ & -0.027 \\
\hline SPD & $\begin{array}{c}-0.426^{* * *} \\
(0.056)\end{array}$ & 0.018 & $\begin{array}{c}0.007 \\
(0.053) \\
\end{array}$ & 0.000 & $\begin{array}{c}0.384^{* \star *} \\
(0.117)\end{array}$ & -0.052 \\
\hline GREENS & $\begin{array}{c}-0.427^{* * *} \\
(0.112)\end{array}$ & 0.002 & $\begin{array}{c}-0.993^{\star * *} \\
(0.153)\end{array}$ & -0.104 & $\begin{array}{c}0.804^{\star \star *} \\
(0.275)\end{array}$ & -0.137 \\
\hline LEFT PARTY & $\begin{array}{c}-1.484^{* * *} \\
(0.263)\end{array}$ & -0.189 & $\begin{array}{c}-0.802^{* * *} \\
(0.283)\end{array}$ & -0.082 & $\begin{array}{l}-0.351 \\
(0.373)\end{array}$ & 0.028 \\
\hline \multicolumn{7}{|c|}{ Regression diagnostics } \\
\hline $\begin{array}{l}\text { p-value joint signifi- } \\
\text { cance of variables }\end{array}$ & \multicolumn{2}{|c|}{0.000} & \multicolumn{2}{|c|}{0.000} & \multicolumn{2}{|c|}{0.000} \\
\hline $\begin{array}{l}\text { p-value joint signifi- } \\
\text { cance party dummies }\end{array}$ & \multicolumn{2}{|c|}{0.000} & \multicolumn{2}{|c|}{0.000} & \multicolumn{2}{|c|}{0.000} \\
\hline Observations & \multicolumn{2}{|c|}{72} & \multicolumn{2}{|c|}{72} & \multicolumn{2}{|c|}{72} \\
\hline $\begin{array}{l}\text { Share correct } \\
\text { classifications } \\
\text { (exact hit/absolute } \\
\text { classification error } \\
<=1 \text { ) }\end{array}$ & \multicolumn{2}{|c|}{$0.325 / 0.554$} & \multicolumn{2}{|c|}{$0.349 / 0.675$} & \multicolumn{2}{|c|}{$0.277 / 0.506$} \\
\hline Pseudo-R2 & \multicolumn{2}{|c|}{0.038} & \multicolumn{2}{|c|}{0.061} & \multicolumn{2}{|c|}{0.029} \\
\hline
\end{tabular}

Party: FDP (liberal party) dummy not included; " marginal effect at mode (Q1: 6, Q2: 7, Q3: 3);

${ }^{* * * / * * *}$ : significant at 10/5/1 percent level. 
Table 8: Ordered probit estimation control group: Tax policy

\begin{tabular}{|c|c|c|c|c|}
\hline \multirow[b]{2}{*}{ Variable } & \multicolumn{2}{|c|}{$\begin{array}{l}\text { Q4: Autonomy of tax policy } \\
\text { Model 2a }\end{array}$} & \multicolumn{2}{|c|}{$\begin{array}{l}\text { Q5: Preference minimum taxes } \\
\text { Model 2b }\end{array}$} \\
\hline & Coefficient & Marginal effect ${ }^{\star}$ & Coefficient & Marginal effect $^{\star}$ \\
\hline \multicolumn{5}{|c|}{ Perceived restrictions } \\
\hline Real mobility (Q1) & $\begin{array}{l}-0.033 \\
(0.103)\end{array}$ & -0.003 & $\begin{array}{c}0.018 \\
(0.100)\end{array}$ & -0.003 \\
\hline Paper profits (Q2) & $\begin{array}{l}-0.012 \\
(0.070) \\
\end{array}$ & -0.001 & $\begin{array}{c}0.004 \\
(0.134)\end{array}$ & -0.001 \\
\hline Yardstick (Q3) & $\begin{array}{l}-0.002 \\
(0.031)\end{array}$ & 0.000 & $\begin{array}{l}-0.052 \\
(0.062)\end{array}$ & 0.007 \\
\hline \multicolumn{5}{|c|}{ Information } \\
\hline Public finance lecture & $\begin{array}{l}0.668^{*} \\
(0.400)\end{array}$ & 0.060 & $\begin{array}{l}-0.052 \\
(0.428) \\
\end{array}$ & 0.007 \\
\hline Number of semesters & $\begin{array}{l}-0.166^{\star *} \\
(0.075)\end{array}$ & -0.013 & $\begin{array}{l}-0.059 \\
(0.134)\end{array}$ & 0.008 \\
\hline \multicolumn{5}{|c|}{ Other individual characteristics } \\
\hline German & $\begin{array}{c}0.205 \\
(0.539)\end{array}$ & 0.020 & $\begin{array}{l}0.622^{*} \\
(0.336)\end{array}$ & -0.061 \\
\hline Female & $\begin{array}{l}-0.085 \\
(0.475) \\
\end{array}$ & -0.007 & $\begin{array}{l}-0.218 \\
(0.553) \\
\end{array}$ & 0.030 \\
\hline \multicolumn{5}{|c|}{ Party preference } \\
\hline CDU/CSU & $\begin{array}{l}0.227^{* \star *} \\
(0.055)\end{array}$ & 0.014 & $\begin{array}{c}0.214 \\
(0.311)\end{array}$ & -0.032 \\
\hline SPD & $\begin{array}{l}0.395^{\star \star \star} \\
(0.098)\end{array}$ & 0.024 & $\begin{array}{l}1.430^{\star \star \star} \\
(0.277)\end{array}$ & -0.195 \\
\hline GREENS & $\begin{array}{l}-0.543^{\star \star \star} \\
(0.098)\end{array}$ & -0.065 & $\begin{array}{l}1.110^{\star \star} \\
(0.565)\end{array}$ & -0.167 \\
\hline LEFT PARTY & $\begin{array}{c}-1.551^{* * *} \\
(0.302)\end{array}$ & -0.212 & $\begin{array}{l}-0.201^{*} \\
(0.111)\end{array}$ & 0.026 \\
\hline \multicolumn{5}{|c|}{ Regression diagnostics } \\
\hline $\begin{array}{l}\text { p-value joint significance } \\
\text { of variables }\end{array}$ & \multicolumn{2}{|c|}{0.000} & \multicolumn{2}{|c|}{0.000} \\
\hline $\begin{array}{l}\text { p-value joint significance } \\
\text { party dummies }\end{array}$ & \multicolumn{2}{|c|}{0.000} & \multicolumn{2}{|c|}{0.000} \\
\hline Observations & \multicolumn{2}{|c|}{72} & \multicolumn{2}{|c|}{72} \\
\hline $\begin{array}{l}\text { Share correct } \\
\text { classifications } \\
\text { (exact hit/absolute classi- } \\
\text { fication error }<=1 \text { ) }\end{array}$ & \multicolumn{2}{|c|}{$0.229 / 0.518$} & \multicolumn{2}{|c|}{$0.244 / 0.439$} \\
\hline Pseudo-R2 & \multicolumn{2}{|c|}{0.056} & \multicolumn{2}{|c|}{0.076} \\
\hline
\end{tabular}

Party: FDP (liberal party) dummy not included; *marginal effect at mode (Q4: 6, Q5: 3); $* / * \star / * \star$ : significant at 10/5/1 percent level. 
Table 9: Ordered probit estimation: Tax policy restrictions with left-right-indicator

\begin{tabular}{|c|c|c|c|c|c|c|}
\hline \multirow[b]{2}{*}{ Variable } & \multicolumn{2}{|c|}{$\begin{array}{c}\text { Q1: Mobility real } \\
\text { capital } \\
\text { Model 1a }\end{array}$} & \multicolumn{2}{|c|}{$\begin{array}{c}\text { Q2: Mobility paper prof- } \\
\text { its } \\
\text { Model } 1 \mathrm{~b}\end{array}$} & \multicolumn{2}{|c|}{$\begin{array}{l}\text { Q3: Yardstick } \\
\text { competition } \\
\text { Model 1c }\end{array}$} \\
\hline & Coefficient & $\begin{array}{c}\text { Marginal } \\
\text { effect }^{*}\end{array}$ & Coefficient & $\begin{array}{c}\text { Marginal } \\
\text { effect }^{\star}\end{array}$ & Coefficient & $\begin{array}{c}\text { Marginal } \\
\text { effect }^{*}\end{array}$ \\
\hline \multicolumn{7}{|c|}{ Education } \\
\hline Secondary (“Abitur”) & $\begin{array}{l}0.350^{\star \star *} \\
(0.128)\end{array}$ & 0.049 & $\begin{array}{c}0.268 \\
(0.342) \\
\end{array}$ & 0.008 & $\begin{array}{l}-0.012 \\
(0.200) \\
\end{array}$ & 0.003 \\
\hline Tertiary & $\begin{array}{c}0.193 \\
(0.172)\end{array}$ & 0.026 & $\begin{array}{l}-0.273 \\
(0.544)\end{array}$ & 0.005 & $\begin{array}{l}-0.194 \\
(0.223)\end{array}$ & 0.045 \\
\hline \multicolumn{7}{|c|}{ Information } \\
\hline Economic/business & $\begin{array}{l}-0.214 \\
(0.430) \\
\end{array}$ & -0.029 & $\begin{array}{c}-0.234^{\star *} \\
(0.109) \\
\end{array}$ & -0.006 & $\begin{array}{c}0.020 \\
(0.209) \\
\end{array}$ & -0.005 \\
\hline "Freiberufler" & $\begin{array}{l}-0.286^{* * *} \\
(0.089)\end{array}$ & -0.040 & $\begin{array}{l}0.405^{\star * *} \\
(0.153)\end{array}$ & -0.013 & $\begin{array}{l}0.278^{\star *} \\
(0.123)\end{array}$ & -0.063 \\
\hline Years in Bundestag & $\begin{array}{l}0.053^{\star \star \star} \\
(0.012)\end{array}$ & 0.007 & $\begin{array}{l}-0.038^{\star \star \star} \\
(0.009)\end{array}$ & -0.000 & $\begin{array}{l}-0.007 \\
(0.016)\end{array}$ & 0.002 \\
\hline $\begin{array}{l}\text { Member financial commit- } \\
\text { tee }\end{array}$ & $\begin{array}{l}0.386^{\star \star \star} \\
(0.118)\end{array}$ & 0.042 & $\begin{array}{l}-0.131 \\
(0.138)\end{array}$ & -0.003 & $\begin{array}{c}0.155 \\
(0.135)\end{array}$ & -0.036 \\
\hline Member budget committee & $\begin{array}{l}-0.399 \\
(0.258)\end{array}$ & -0.057 & $\begin{array}{c}0.302 \\
(0.365) \\
\end{array}$ & -0.006 & $\begin{array}{c}0.026 \\
(0.098)\end{array}$ & 0.006 \\
\hline \multicolumn{7}{|c|}{ Other individual characteristics } \\
\hline Eastern Germany & $\begin{array}{c}0.277 \\
(0.234)\end{array}$ & 0.032 & $\begin{array}{c}-0.871^{\star \star \star} \\
(0.153)\end{array}$ & -0.070 & $\begin{array}{l}0.770^{* * *} \\
(0.213)\end{array}$ & -0.163 \\
\hline Female & $\begin{array}{l}0.566^{\star * \star} \\
(0.189)\end{array}$ & 0.062 & $\begin{array}{l}0.307^{*} \\
(0.173)\end{array}$ & -0.003 & $\begin{array}{c}0.122 \\
(0.161)\end{array}$ & -0.028 \\
\hline Party list & $\begin{array}{l}-0.153 \\
(0.168) \\
\end{array}$ & -0.020 & $\begin{array}{l}-0.259^{* \star *} \\
(0.073)\end{array}$ & -0.001 & $\begin{array}{l}-0.255^{\star} \\
(0.132) \\
\end{array}$ & 0.059 \\
\hline Age & $\begin{array}{l}-0.012 \\
(0.008)\end{array}$ & -0.002 & $\begin{array}{c}0.011 \\
(0.007)\end{array}$ & 0.000 & $\begin{array}{c}0.002 \\
(0.008)\end{array}$ & -0.000 \\
\hline \multicolumn{7}{|c|}{ State characteristics } \\
\hline Unemployment rate & $\begin{array}{c}0.015 \\
(0.022) \\
\end{array}$ & 0.002 & $\begin{array}{c}0.095 \\
(0.068) \\
\end{array}$ & 0.001 & $\begin{array}{l}-0.056^{\star} \\
(0.032)\end{array}$ & 0.013 \\
\hline GDP per capita & $\begin{array}{c}0.000 \\
(0.000) \\
\end{array}$ & 0.002 & $\begin{array}{c}0.000 \\
(0.000) \\
\end{array}$ & 0.000 & $\begin{array}{c}0.000 \\
(0.000) \\
\end{array}$ & 0.000 \\
\hline \multicolumn{7}{|c|}{ Party } \\
\hline $\begin{array}{l}\text { Left-right indicator } \\
\text { Benoit/Laver (2006) }\end{array}$ & $\begin{array}{l}0.209^{\star \star \star} \\
(0.037)\end{array}$ & 0.027 & $\begin{array}{c}-0.124^{\star \star \star} \\
(0.033)\end{array}$ & -0.001 & $\begin{array}{c}0.029 \\
(0.028)\end{array}$ & 0.007 \\
\hline \multicolumn{7}{|c|}{ Regression diagnostics } \\
\hline $\begin{array}{l}\text { p-value joint significance } \\
\text { of variables }\end{array}$ & \multicolumn{2}{|c|}{0.000} & \multicolumn{2}{|c|}{0.000} & \multicolumn{2}{|c|}{0.000} \\
\hline Observations & \multicolumn{2}{|c|}{157} & \multicolumn{2}{|c|}{156} & \multicolumn{2}{|c|}{157} \\
\hline $\begin{array}{l}\text { Share correct } \\
\text { classifications } \\
\text { (exact hit/absolute classifi- } \\
\text { cation error }<=1 \text { ) }\end{array}$ & \multicolumn{2}{|c|}{$0.223 / 0.694$} & \multicolumn{2}{|c|}{$0.276 / 0.686$} & \multicolumn{2}{|c|}{$0.217 / 0.465$} \\
\hline Pseudo-R2 & \multicolumn{2}{|c|}{0.115} & \multicolumn{2}{|c|}{0.076} & \multicolumn{2}{|c|}{0.017} \\
\hline
\end{tabular}

*marginal effect at mode (Q1: 7, Q2: 7, Q3: 2); ${ }^{* * * / * * *}$ : significant at 10/5/1 percent level. 